\title{
Subterranean Crustacea Decapoda Macrura Collected by Mr. L. Botosaneanu during the 1973 Cuban-Roumanian Biospeological Expedition to Cuba
}

\author{
by
}

\section{B. HOLTHUIS*}

To date three expeditions to explore the cave fauna of Cuba have been undertaken under the auspices of the Academies of Sciences of Roumania and Cuba; in 1969, 1970 and 1973. A paper on the cave shrimps collected by the first (1969) expedition has been published (Botosaneanu \& Holthuis, 1970). In that paper a review was given of the state of our knowledge of the subterranean shrimp fauna of Cuba as it was at that time, with a list of all species and references to all publications dealing with them. The 1969 expedition not only collected all species of cave shrimps then known from Cuba, but also one that was new to science.

The 1973 expedition added one species to this list, the material of which represents an undescribed subspecies. The number of subterranean species of shrimps collected in 1973 is smaller than that obtained in 1969, but interesting range extensions and important data on the ecology of the species could be added.

In the present paper not only the shrimps are treated, but crayfishes are included as well. During the expedition Mr. Botosaneanu also collected 2 species of Macrura in epigean fresh waters, viz., a shrimp, Atya scabra (Leach, 1815) in Rio San Vicente near Viñales, Pinar del Rio Province, and the crayfish Procambarus atkinsoni (Ortmann, 1913) in Arroyo La Talega near Santa Fé, Isla de Pinos. Two species of marine Thalassinidea were likewise obtained by Mr. Botosaneanu: a specimen of Callianassa jamaicensis Schmitt, 1935, and some specimens of Axianassa intermedia Schmitt, 1924; both were collected at Playa Siboney, east of Santiago de Cuba, at a small beach of coarse sand with many coral fragments.

I wish to express here my sincere thanks to Mr. L. Botosaneanu of the Institutul de Speologie "Emil Racovitza", Bucharest, for placing this material at my disposal, and for providing extensive descriptions of the habitats and biology of the animals, which have been cited almost verbatim in the present paper.

The abbreviation cl. has been used to indicate the carapace length.

\section{PALAEMONIDAE}

\section{Troglocubanus gibarensis (Chace, 1943)}

Troglocubanus gibarensis Botosaneanu \& Holthuis, 1970: 129.

Cueva de los Panaderos near Gibara, near the N.W. coast of Oriente province, Cuba;

*) Rijksmuseum van Natuurlijke Historie, Leiden, Netherlands 


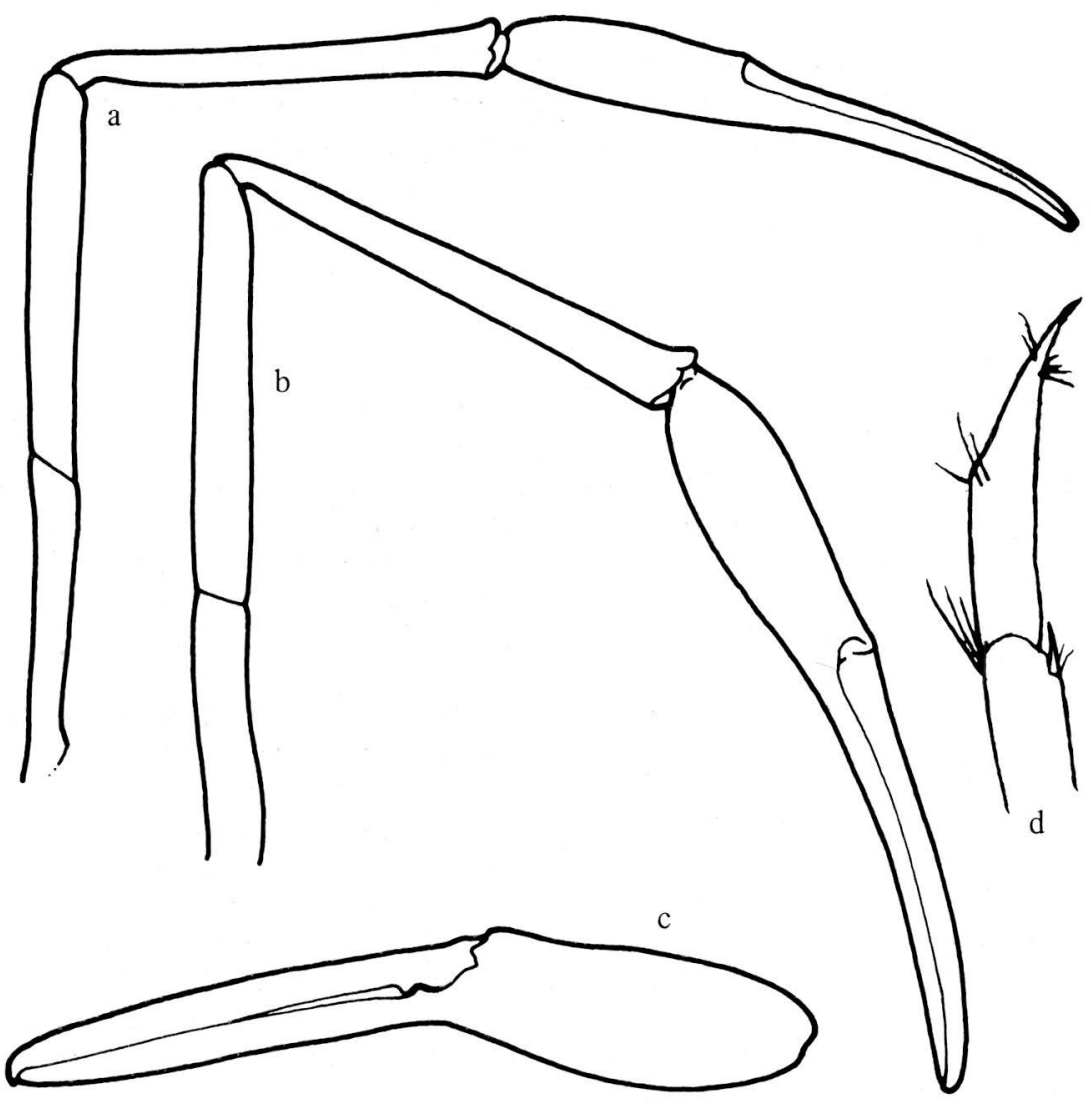

Fig. 1. Troglocubanus gibarensis (Chace). a-c, second leg of larger female; d, dactylus of third leg. a-c, x 12; b, x 50.

8 March 1973, leg. L. Botosaneanu, helped by A. Graña and José M. Marrero. 9 specimens, cl. 5 to $11 \mathrm{~mm}$.

This cave lies about $2 \mathrm{~km}$ from Gibara at an altitude of $20 \mathrm{~m}$ above sea level. Its opening is in the so-called Loma de Cupeycillo, situated on the second or third marine terrace, in a region with abundant vegetation. The distance between the entrance of the cave and the sea is less than $1 \mathrm{~km}$, but the distance between the sea and the phreatic lakes in the caves is not known. The cave is rather large, about 500 $\mathrm{m}$ long; at the end it descends abruptly to a body of water consisting of a row of two or three "lakes", separated by mounds of clastic material fallen down from the ceiling of the cave. The length of these lakes in the explored part of the cave is 
about $30 \mathrm{~m}$, their depth usually lies between 0.5 and $1.5 \mathrm{~m}$, (sometimes the depth is greater), and their width lies between 2 and $3 \mathrm{~m}$, sometimes more. The water at the day of collecting was slightly brackish, but the salinity evidently is variable. On the bottom there is a heavy layer of silt ( 30 to $40 \mathrm{~cm}$ thick). The water temperature was $24^{\circ} \mathrm{C}$.

The specimens agree well with the published descriptions. The rostrum in one of the specimens bears four dorsal teeth, in the other two this number is three. The two largest females have both the second chelipeds attached. In the smaller specimen $(\mathrm{cl} .10 \mathrm{~mm})$ the fingers are 1.5 times as long as the palm and bear each a small tooth in the extreme proximal part of the cutting edge. The palm is hardly swollen. The carpus is 0.7 times the length of the chela and is distinctly longer than the merus. In the larger female $(\mathrm{cl} .11 \mathrm{~mm})$ the palm is somewhat more swollen, and the teeth on the cutting edges are more distinct (fig. $1 \mathrm{a}-\mathrm{c}$ ).

In these specimens the dactyli of the last three legs sometimes show an angular outline dorsally; at the angle a small tuft of hairs is implanted (fig. $1 \mathrm{~d}$ ).

The present material was collected rather close to the type locality (Aguada del Montañes, El Jobal, Termino de Gibara, Oriente province). Apart from the type material and the specimens reported upon by Botosaneanu \& Holthuis (1970), no material of this species has so far been reported upon in the literature.

Troglocubanus eigenmanni (Hay, 1903)

Troglocubanus eigenmanni Botosaneanu \& Holthuis, 1970: 128.

"Pozzo-criollo" at the foot of Cerro los Cheo, a few km from Santa Fé, Isla de Pinos; 24 April 1973, leg. L. Botosaneanu. - 2 specimens, cl. 15 mm.

The specimens agree well with the descriptions given in the literature. The rostral formulae are $4 / 8$ and $3 / 7$.

The animals were taken in a not too deep neglected well in the courtyard of a deserted farm at the foot of a moderately high hill which is called by the people of the area "Cerro los Cheo". It is not marked under that name on the map. This hill forms part of a range called Cerro la Jia or Cerro de Jagual. The well is about $5 \mathrm{~m}$ deep; the bottom consists of chalk and is covered with stones.

It is interesting that the species of Troglocubanus with the widest distribution in Cuba also occurs on the Isla de Pinos, which is situated at about $50 \mathrm{~km}$ from the mainland of Cuba. This is, as far as I know, the first record of a subterranean shrimp from the Isla de Pinos.

Macrobrachium faustinum (de Saussure, 1857) ssp. lucifugum new subspecies

Macrobrachium olfersii p.p. Rathbun, 1919: 324.

Macrobrachium olfersi Hummelinck, 1933: 319.

Macrobrachium olfersii Schmitt, 1936: 372.

Macrobrachium sp. (near M. faustinum) Chace \& Holthuis, 1948: 23.

Macrobrachium aff. faustinum Holthuis, 1952: 94, 95. 
Cueva del Agua de Yara, on the territory of the "barrio" Yara, E. of Baracoa, Oriente province, Cuba; 21 February 1973, leg. L. Botosaneanu, D. Deas and A. Boudet. - 2 females, cl. (with rostrum) 23 and $30 \mathrm{~mm}$ (the largest specimen is the holotype).

Cueva de los Panaderos near Gibara, near the northwest coast of Oriente province, Cuba; 9 March 1973, leg. L. Botosaneanu helped by A. Graña and José M. Marrero. - 2 males, cl. (without rostrum) 15 and $18 \mathrm{~mm}$, (with rostrum) 22 and 26 $\mathrm{mm}$.

Marine cave (flooded by sea water) near Playa Caletone, Gibara region, Oriente province, Cuba; 10 March 1973, leg. L. Botosaneanu, helped by A. Graña and José M. Marrero. - 18 specimens cl. (without rostrum) $4-17 \mathrm{~mm}$, (with rostrum) 7 $28 \mathrm{~mm}$.

Cueva del Palmero, near a place called "La Caoba" or "El Rincón del Palmero" not far from the highway between Quemado Pineda and Santo Tomás-Moncada, Pinar del Rio province, Cuba; 13 April 1973, leg. L. Botosaneanu helped by C. Camacho and L. Rodriguez Malagon. - 1 damaged specimen.

The Cueva del Agua de Yara is a small cave in the first marine terrace at $350 \mathrm{~m}$ from the sea. The water comes close to the entrance and fills almost the whole of the single chamber of which the cave consists. The water is 1.5 to $2 \mathrm{~m}$ deep, clear, and (at the time the specimens were collected) slightly brackish, practically fresh. The waterlevel is influenced by the tides. On the bottom there are rocks and pieces of decaying wood. The temperature is $24^{\circ} \mathrm{C}$.

In the Cueva de los Panaderos, apart from Macrobrachium, also Troglocubanus gibarensis was found, the habitat being more extensively described under the latter species (p. 232). The present specimens were observed in the deeper parts of the pools near the walls.

The marine cave near Playa Caletone is flooded by sea water, it lies about $300 \mathrm{~m}$ east of Playa Caletone and 17 to $18 \mathrm{~km}$ west of Gibara; it is situated about $8 \mathrm{~km}$ east of the locality where Barbouria cubensis was found (see p. 240). The cave lies close to the road and to the sea shore. It is a marine cave the roof of which is collapsed, and resembles thereby a large sink hole filled with sea water. Part of the water is in bright day light, part in the dark. The water is deep and strongly brackish, its salinity being almost as high as that of sea water. The fauna and flora are marine and very abundant.

The Cueva del Palmero consists of a short descending gallery which leads to a phreatic pool, which shows as a lake in the semidarkness. The water depth is 2 to 3 $\mathrm{m}$; the bottom consists of coarse sand mixed with bat guano. The shrimp was taken on bait.

Description. - - The rostrum reaches slightly beyond the end of the scaphocerite, it is rather slender and tapers to a slender tip, which shows no subapical tooth. The upper margin is faintly convex over the eyes and faintly concave beyond the eyes, the tip is thereby directed slightly upward. There are 12 to 15 dorsal teeth, the first 6 or 5 of which (in juveniles 3 or 4 ) stand behind the orbit on the carapace. The distal dorsal teeth become gradually more widely spaced distally. The 


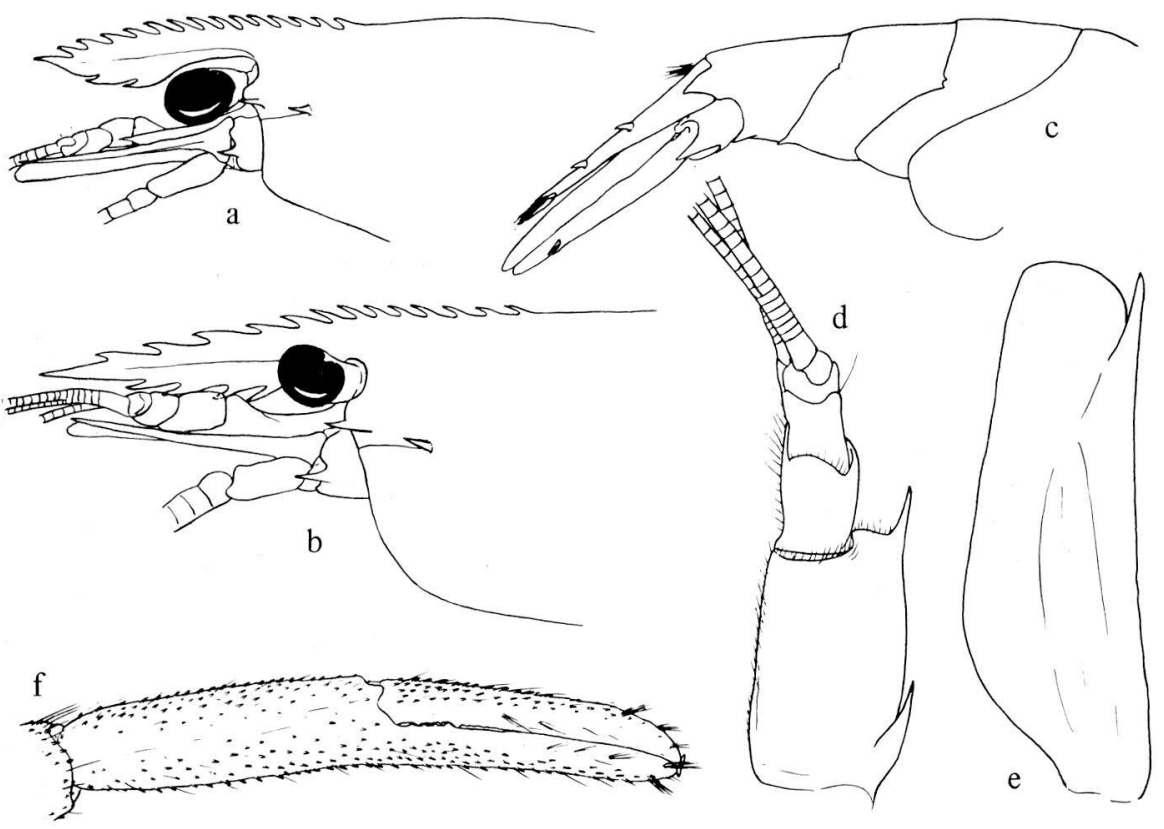

Fig. 2. Macrobrachium faustinum lucifugum new subspecies, from cave near Playa Caletone. a, specimen resembling the typical form; b-f, characteristic specimen of ssp. lucifugum. a, $\mathrm{b}$, anterior part of body in lateral view; c, abdomen in lateral view; d, antennula; e, scaphocerite; $f$, chela of second leg. a-c, 6 ; d-f,x 12 .

lower margin bears 3 or 4 , sometimes 5, teeth, leaving a distinct distal part unarmed. In a few specimens from the marine cave near Playa Caletone the rostrum is less slender and shorter, reaching to or almost to the end of the scaphocerite, while the teeth are less widely spaced (fig. 2 a). These specimens thereby resemble the typical subspecies, and might well have accidentally entered the subterranean habitat, as all other specimens of this lot have the longer rostrum. It is interesting to see that part of the area of this cave in which was collected is exposed to bright day light.

The antennal spine is placed slightly below the rounded lower orbital angle. The hepatic spine is about as strong as the antennal and is placed below and behind the latter; a distinct branchiostegal line connects the hepatic spine with the anterior margin of the carapace. The anterolateral angle of the carapace is broadly rounded. The surface of the carapace is smooth.

The abdomen has the pleura of the first four somites broadly rounded. The pleura of the fifth somite end in a small sharp tooth. The pleura and the posterolateral angles of the sixth somite also end in a small tooth. The sixth somite is 1.5 times longer than the fifth and has about $2 / 3$ of the length of the telson. The dorsal spines of the telson are placed at about $1 / 2$ and $3 / 4$ of the length of the 
telson. The posterior margin ends in a strong acute median point, which is distinctly overreached by the long intermediate posterior spines, the outer spines are short. Between the intermediate spines there are many long and strong hairs.

The eyes are rather well developed. The cornea is distinct and globular, being clearly wider than the stalk. A distinct ocellus is present.

The antennulae are slender. The stylocerite reaches about to the middle of the basal segment. The anterolateral angle of the basal segment ends in a strong tooth which reaches distinctly beyond the middle of the second segment. The second and third segments are of about equal length; together they are shorter than the basal segment. The two branches of the upper antennular flagellum are fused only for a very short distance. Of the shorter flagellum the free part has the internal margin somewhat serrate.

The scaphocerite reaches with about $1 / 4$ to $1 / 3$ of its length beyond the antennular peduncle. It is about three times long as wide. The outer margin is almost straight and ends in a sharp and strong tooth, which almost or quite attains the end of the anteriorly truncate lamella. The antennal peduncle fails by far to reach the middle of the length of the scaphocerite. A strong spine is present near the outer base of the scaphocerite.

The mouth parts are normal. The mandible has a distinct palp formed of three clearly separated segments. The incisor process has three teeth, the molar process ends in a number of blunt teeth. The upper and lower laciniae of the maxillula are slender, the palp is deeply bilobed. The endite of the maxilla is deeply cleft. The maxillipeds bear well developed exopods. The first maxilliped has the two endites separated by a notch, the palp has the distal part narrow, the caridean lobe is broad and the epipod is distinctly bilobed. The second maxilliped has a large podobranch. The third maxilliped reaches about as far as the end of the antennular peduncle. The last segment is slightly shorter than the penultimate, which measures $2 / 3$ of the length of the antepenultimate. The exopod is strong, an epipod, an arthrobranch and a pleurobranch are present.

The first pereiopod reaches with less than half the carpus beyond the scaphocerite. The fingers are somewhat shorter than the palm. The carpus is distinctly less than twice as long as the chela and clearly longer than the merus.

The second pereiopods are about equal in the specimens examined. They reach with part of the carpus beyond the scaphocerite. They are similar left and right. The fingers are about as long as the palm. They show a small tooth in the basal part of the cutting edges, behind which there are a few smaller denticles. The cutting edge of the fingers distally of the larger tooth is even or slightly crenulated, as if in larger individuals denticles will be formed there. The palm is cylindrical. Scattered hairs and spinules are placed all over the cheliped, but the hairs do not form a conspicuous pubescence. The carpus is elongate and slender, being more than four times as long as wide. It measures $4 / 5$ of the length of the chela and is about $4 / 3$ as long as the merus. The merus is slightly longer than the ischium.

The third leg reaches with part of the propodus beyond the scaphocerite. The dactylus is somewhat more than $1 / 4$ of the length of the propodus. The propodus bears a row of 10 to 12 spines along the posterior margin; it is about 1.7 times as 
long as the carpus and somewhat shorter than the merus. The fourth leg resembles the third. The fifth leg reaches with part of the propodus beyond the scaphocerite, it is much more slender than the third. The propodus is four times as long as the dactylus, it bears a few spinules on the posterior margin and has rows of hair in the distal part of the posterior margin. It is 1.7 times as long as the carpus and longer than the merus.

Types. - - Holotype is the largest female from Cueva del Agua, all the other material dealt with here are paratypes. The holotype is in the collection of the Rijksmuseum van Natuurlijke Historie, Leiden, under Reg.no. Crust. D. 29846.

Apart from the Cuban specimens, the Rijksmuseum van Natuurlijke Historie possesses material of this subspecies from the following localities:

Green Grotto Cave, northcoast of Jamaica between Discovery Bay and Runaway Bay, about $18^{\circ} 28^{\prime} \mathrm{N} 77^{\circ} 21^{\prime} \mathrm{W} ; 18$ February 1971 , leg. P. Colin, don. D. Opresko. $1 \mathrm{male}$, cl. $34 \mathrm{~mm}$ (with rostrum), $20 \mathrm{~mm}$ (without rostrum).

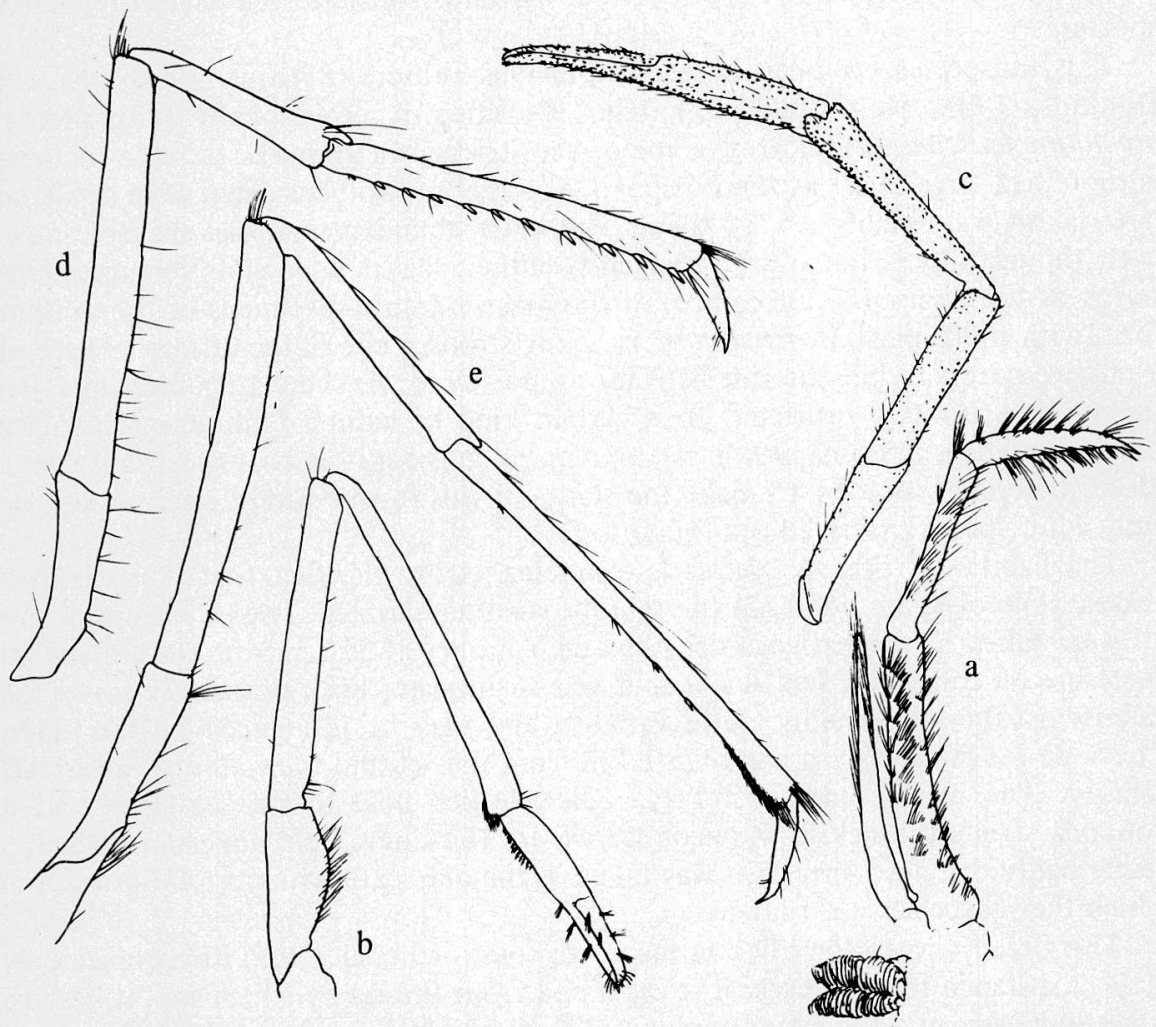

Fig. 3. Macrobrachium faustinum lucifugum new subspecies, characteristic specimen from cave near Playa Caletone. a, third maxilliped; $b$, first pereiopod; $c$, second pereiopod; $d$, third pereiopod; e, fifth pereiopod. a, b, d, e,x12; c,x6. 
Sjingod, $4 \mathrm{~km}$ W.N.W. of Hato airport, N.E. coast of Curaçao, Netherlands Antilles, a cave about $60 \mathrm{~m}$ from the sea; 24 April 1960, leg. I. Kristensen. - 3 specimens, cl. $20-23 \mathrm{~mm}$ (with rostrum), $12-15 \mathrm{~mm}$ (without rostrum).

The specimen from Jamaica is rather large, but unfortunately possesses only one of the second legs. This leg resembles the smaller second leg of the almost adult male of Macrobrachium $f$. faustinum, being only slightly more slender; the fingers gape slightly and have stiff hairs on the cutting edges, they are slightly longer than the palm; the carpus is more slender than in $M . f$. faustinum, being slightly less than four times as long as wide.

The present form, which might be considered a subspecies of Macrobrachium faustinum (de Saussure), differs from the typical form in the far longer and more slender rostrum of which the distal teeth are far wider separated. The legs are also more slender than in $M . f$. faustinum, this is especially noticeable in the second leg, of which the right and left seem to be less different; the carpus is about four or more than four times as long as wide, and the merus is only slightly longer than the ischium. The last three legs reach farther forwards and have the dactyli relatively shorter.

This subspecies has been noted by previous authors (Schmitt, 1936; Chace \& Holthuis, 1948; Holthuis, 1952), who identified it provisionally with Macrobrachium faustinum, indicating some of the striking differences. As none of these authors had large series at their disposal, and as the specimens often were small, no new taxon was established by them. The more abundant material available now, even though this is not quite satisfactory either, makes it possible to suggest the status of the form. The differences of the most extreme specimens of the present form with the typical $M$. faustinum are quite striking, but all the differences are of a relative nature, while intermediate forms are found. As there are indications that the present form is restricted to a certain kind of habitat (subterranean, often brackish water), it seems best in my opinion to consider it an ecological subspecies. More material is needed to make the status of this form entirely clear, as still no fully adult specimens have been found so far.

The habitat of this subspecies is characterized by the fact that (1) it is dark (caves, sinkholes, etc.) and (2) the salinity is rather elevated. The Cuban specimens all were taken in caves. Cueva del Agua de Yara lies at $350 \mathrm{~m}$ from the sea and, at the time of collecting, had water that was slightly brackish, practically fresh; the salinity is almost certainly quite variable, and may be influenced by the tides. Cueva de los Panaderos is less than $1 \mathrm{~km}$ from the sea and the water has a variable salinity. The marine cave near Playa Caletone lies close to the sea shore and it contains strongly brackish water or sea water. The Cueva del Palmero, in which a single badly damaged specimen was taken, is the only cave with pure fresh water in which the subspecies was found.

The Green Grotto Cave lies on the north coast of Jamaica with its entrance only a short distance from the sea; it is separated from the sea by a highway. It lies in a limestone area, and the major pool is said to be brackish and under the influence of the tides. The cave system is rather extensive and has several entrances; it is inhabited by bats, while fishes (supposedly mullet) are found in the water with the shrimps (information kindly provided by Dr. Anthony J. Provenzano, Miami). 
Sjingod, Curaçao, was described by Hummelinck (1953: 35, 45) as a "cave with narrow entrance, $6 \mathrm{~m}$ below plateau", the water of which is "stagnant; permanent ... with tidal movements". The cave is in limestone rock, the bottom is covered with a clayish substance, the water is clear and colourless, the salinity in 1949 was 3260 $\mathrm{mg} \mathrm{Cl} / \mathrm{l}$. The cave, in which there is hardly any light, measures about 20 by $10 \mathrm{~m}$, the depth is about $3 \mathrm{~m}$, it lies $60 \mathrm{~m}$ from the sea.

The localities for the subspecies mentioned in the literature all are situated on the island of Bonaire, Netherlands Antilles, and are the following:

"Playa, 1/4 fathom, corals, small hand-net" (Rathbun, 1919: 324). The exact situation of this locality is unknown to me, nor do I know the ecological conditions in which the specimen was found.

"Pos Caranja, in a dim excavation filled with mesohaline water" (Schmitt, 1936: 372). "Pos Caranja, W. Lima, in well, shadow ... in mesohaline water" (Chace \& Holthuis, 1948: 23). Hummelinck (1933: 314, fig. 11) figured this locality and described it as a sinkhole in coral limestone with the "Grundwasserspiegel $1-1,20$ $m$ unter der Plateauoberfläche". The water, as already indicated by Schmitt (1936), and Chace \& Holthuis (1948) is mesohaline; Hummelinck (1953: 42) described it as being subject to tidal influence. The bottom of the well consists of rock and black mud with a coating of microscopic algae. The size of the water body is $4.5 \times 2 \times 1-3$ $\mathrm{m}$, it is permanent with stagnant, clear and colourless water.

"Pos di Booi" (Schmitt, 1936: 372) is a sinkhole similar to Pos Caranja and probably connected with it subterraneously. The salinity of the water was $2940 \mathrm{mg}$ Cl/1 (Hummelinck, 1933: 313, 315).

"Pos Calbas, Lima, in well, shadow" (Chace \& Holthuis, 1948: 23). This sinkhole lies, like the previous two, near the west coast of southern Bonaire, S. of Kralendijk; it is situated somewhat to the N.E. of the Pos Caranja complex. Hummelinck (1953: 34, 42) described it as a sink hole in coral limestone rock with the bottom covered by black mud with calcite crystals. The water is stagnant and permanent, it is clear, colourless and subject to tidal movements. The depth is about 0.25 to $3 \mathrm{~m}$, the surface of the water body is 10 by $7 \mathrm{~m}$. In 1937 the salinity was $880 \mathrm{mg} \mathrm{Cl} / 1$, in 1948 and 1949 1450-1520 mg Cl/l.

All the localities whence the present subspecies has been found seem to share the characters of darkness and high salinity.

The geographic distribution of the new subspecies is a rather extensive West Indian one, having been found in Cuba, Jamaica, Curaçao and Bonaire. The epigean form of Macrobrachium faustinum also has a wide West Indian distribution, and has frequently been reported from Cuba.

\section{HIPPOLYTIDAE}

Barbouria cubensis (Von Martens, 1872)

Barbouria cubensis Botosaneanu \& Holthuis, 1970: 131.

"Casimba" near Playa Velazques, Gibara area, Oriente province, Cuba; 10 March 1973, leg. L. Botosaneanu, A. Graña and José M. Marrero, no. $41-8$ specimens cl. $7-12 \mathrm{~mm}$. 
The above locality is situated 9 to $10 \mathrm{~km}$ west of Gibara, about halfway between Gibara and Playa Caletone, very close to the road that connects these two places. It is a small pool in the quarternary coral rock, about $80 \mathrm{~m}$ from the sea shore. It is 5 $\mathrm{m}$ long, $1.5 \mathrm{~m}$ wide, situated in an area with a rich vegetation. Its bottom consists of sand, mud with an $\mathrm{H} 2 \mathrm{~S}$ odour, and a number of blocks of madreporarian coral. The water surface occupies an area of $2 \mathrm{~m}^{2}$. The maximum depth of the water at the time of collecting was $25 \mathrm{~cm}$, but the level is strongly influenced by the tides. The temperature of the water is $28^{\circ} \mathrm{C}$. The water was distinctly brackish. No large clefts or cracks were visible in the walls of this pool, but it is almost certain that subterranean passages leading away from it do exist. The "casimba" is well exposed to the sunshine, but is shady in a few places.

Barbouria was very plentiful in this small pool: more than 300 specimens of various size were observed in it. The animals were resting on the surface of the rocks, but when disturbed hid themselves quite rapidly among the stones and about 10 minutes after the first disturbance not a single shrimp could be observed anymore.

The colour of the animals is rather variable: they may be red, pink, or whitish. This colour evidently depends on the state of contraction or expansion of the red chromatophores, as is seen in so many shrimps inhabiting anchialine habitats.

Recently a photograph of Barbouria cubensis was published as pl. 24 of vol. 1 (1973) of "Résultats des expéditions biospéologiques cubano-roumaines à Cuba"; this plate evidently does not belong to any part of the text of the volume. The explanation of the plate states that the animal shown originates from a "grieta" in the province Matanzas; as Dr. Botosaneanu confirmed, this is one of the specimens from Punta de Guana about $2 \mathrm{~km}$ from Matanzas, reported upon by Botosaneanu \& Holthuis (1970).

Since the report by Botosaneanu \& Holthuis (1970) was written, the present species has been found at a second locality outside Cuba, viz., in a pond at the island of Abaco, Bahama Islands. Instead of being an endemic of Cuba, as has been thought for a long time, the range of the species thus is much wider.

\section{DECAPODA MACRURA REPTANTIA ASTACIDAE}

\section{Procambarus niveus Hobbs \& Villalobos, 1963}

Cueva del Segundo Cauce, part of Gran Caverna de Santo Tomás, Sierra de los Organos near the village Quemado Pineda, Pinar del Rio province, Cuba; 12 April 1973, leg. L. Botosaneanu, Domingo Deas and José M. Marrero. - 6 males, cl. 17 $25 \mathrm{~mm}$, and 2 females, cl. 15 and $22 \mathrm{~mm}$.

The Gran Caverno de Santo Tomás is the largest cave of Cuba and even of Latin America, consisting of a system of galleries situated on various horizontal levels, one above the other. On the lowest level there is a permanent subterranean stream. 
The next higher level contains the Cueva del Segundo Cauce, which only receives water from the subterranean stream after heavy rains, when the flooding of the river makes it possible to reach this higher level. The galleries at still higher levels are entirely dry. The Cueva del Segundo Cauce is situated at an altitude of about $150 \mathrm{~m}$ and is a large, almost straight gallery. A part of it, which bears the name "Cueva de las Represas", is characterized by that it contains a great number of permanent pools, the bottom and sides of which consist of rough hardened calcareous mud, sometimes covered with a layer of soft mud. The pools are of various shapes, and their depth varies from $2-5 \mathrm{~cm}$ to $1.5-2 \mathrm{~m}$. The temperature of the water is $20^{\circ}$ to $21^{\circ} \mathrm{C}$. In the dry season these permanent pools are isolated, separated from each other by barriers of calcified mud. But when after heavy rains the subterranean river penetrates this level of the caves, it forms a connection between the several pools. The pools hold enough water to last them from one flood to another; they also receive water coming down through the ceiling as is shown by the presence of stalactites in these caves.

The crayfish are found in the large to very large pools, sometimes single, sometimes in small groups. There are large and small specimens. Their colouration is quite variable, except for the eyes which are always black. A count was made of the crayfishes in this gallery and a total of 50 were noted. The same kind of crayfish was also observed (but not collected) in a subterranean stream which runs at a lower level, viz., in the active zone of the cave.

The species has been extensively described and figured by Hobbs \& Villalobos (1963: 342, pls. 4, 5), who obtained their type material likewise from the Cuevas de Santo Tomás. The species is easily recognizable.

\section{SUMMARY}

During the 1973 Cuban Roumanian Biospeological Expedition to Cuba 5 species of cavernicolous Decapod Crustacea were collected: the Palaemonidae Troglocubanus gibarensis Chace, T. eigenmanni (Hay) and Macrobrachium faustinum lucifugum new subspecies. The second of these species now is reported for the first time from Isla de Pinos. The third form proved to be a new subspecies of Macrobrachium faustinum (De Saussure), a freshwater shrimp which is widely distributed in the West Indies. The new subspecies is not only known from Cuba, but also material from Jamaica, Curaçao and Bonaire is reported. A new locality is reported for Barbouria cubensis (Von Martens). The Astacid Procambarus niveus Hobbs \& Villalobos was collected near its type locality.

\section{RESUME}

Cinq espèces de Crustacés Décapodes ont été recueillies en 1973 à Cuba au cours de l'expédition biospéologique cubano-roumaine. Trois Palémonidés: Troglocubanus gibarensis Chace, T. eigenmanni (Hay) et Macrobrachium faustinum lucifugum $\mathrm{n}$. 
ssp.; la seconde de ces espèces est citée pour la première fois de l'Isla de Pinos; la troisième forme s'est avérée être une nouvelle sous-espèce de Macrobrachium faustinum, Crevette dulçaquicole largement répandue dans les Antilles; la nouvelle sous-espèce n'est pas connue que de Cuba, mais a déjà été rencontrée dans du matériel provenant de la Jamaïque, de Curaçao et de Bonaire (Antilles néerlandaises). L'Hippolytidé, Barbouria cubensis (Von Martens) est cité d'une nouvelle localité. L'Astacide Procambarus niveus Hobbs et Villalobos, a été capturé près de sa localité type.

\section{REFERENCES}

BOTOSANEANU, L. \& HOLTHUIS, L. B., 1970. Subterranean shrimps from Cuba (Crustacea Decapoda Natantia). Trav. Inst. Spéol. "Emile Racovitza", 9: 121-133, figs. 1, 2.

CHACE, F. A. \& HOLTHUIS, L. B., 1948. Land and fresh water decapod Crustacea from the Leeward Group and northern South America. Studies Fauna Curaçao, Aruba, Bonaire Venezuelan Islands, 3 pt. 12: 21-28.

HOBBS, H. H. \& VILlALOBOS, A., 1964. Los cambarinos de Cuba. An. Inst. Biol. Mexico, 34: 307-366, pls. 1-8, 4 maps.

HOLTHUIS, L. B., 1952. The subfamily Palaemoninae. A general revision of the Palaemonidae (Crustacea Decapoda Natantia) of the Americas. II. Occ. Pap. Allan Hancock Found., 12: 1-396, text-fig. 1, pls. 1-55.

HUMMELINCK, P. W., 1933. Reisebericht. Zoologische Ergebnisse einer Reise nach Bonaire, Curaçao und Aruba im Jahre 1930. No. 1. Zool. Jahrb. Syst., 64: 289-326, figs. 1-14. 1953. Description of new localities. Studies on the Fauna of Curaçao and other Caribbean Islands, 4: 1-90, figs. 1-25, pls. 1-8.

RATHBUN, M. J., 1919. Stalk-eyed crustaceans of the Dutch West Indies. In: J. Boeke, Rapport betreffende een voorloopig onderzoek naar den toestand van de visscherij en de industrie van zeeproducten in de kolonie Curaçao, 2: 317-348, figs. 1-5.

SCHMITT, W. L., 1936. Macruran and Anomuran Crustacea from Bonaire, Curaçao and Aruba. Zoologische Ergebnisse einer Reise nach Bonaire, Curaçao und Aruba im Jahre 1930. No. 16. Zool. Jahrb. Syst., 67: 363-378, pls. 11-13. 